\begin{tabular}{|l|l|ll|l|l|} 
Wewsi. Strarigr. & $5(1)$ & 18 & 30 & - & Beriin. Sturgart, 20.7.1976 \\
\hline
\end{tabular}

Flandrian, a formation or just a name ${ }^{2}$

by R. Paepe, J. Sommé, N. Cunat and C. Baeteman 2

Centre for Quaternary Stratigraphy

1 This paper was presented at the INQUA-Symposium, Uppsala, 1975.

2 Authors" addresses: R. Paepe and C. Baeteman, Geological Survey of Belgium, Quaternary Geology Depr. Yrije Universiteic, Brussel/Belgiurn. J. Somsí and N. Cunat, Inrirut de Géograp̣hie, Université des Sciences et Techniques, Lille/Frances. 
Absract. The name Flandrian is now used to indicare deposits of the Flandrian rransgression or of the Holocene as a whole, in particular in Anglo-Saxon Jirerature. As most geological connorations, Flandrian has changed significance and chronostratigraphic age since it was creased in 1885 by Rutot and VAN DEN BROECX.

At that tine, Flandrian was a pleistocene "assise" which occurred ar the end of long series of quacernary and rertiary stages. Therefore, is corplered and scill compleces the geological rradizion of the cenozoic sequence.

Substages of the Flandrian, as Calais and Dunkerque, are generally used, aithough there only exist type areas of boch series instead of rype localinies. Work is going to define the type section in borh areas of the Flemish Coastal Plain. It would be weful to re-establish the Flandrian stage on basis of these new investigutions, as the last chronostratigraphic member of a concinuous series in the cenozoic stratigraphical sequeace.

Zusammenfassung. Der Name "Flandrian" wird heutzurnge, insbesondere in der angelsäcsischen Licerazur, verwand, um Ablagerungen der Flandrischen Transeression oder des Holozäns ajs Gesamtes zu benennen. Wie die meisten geologisten Namen bar „Fiandrian" sowohl seine Bedeutung als aud sein dronostrarigraphisches Alter seit seiner Erstrerwendung durch Rutor und VAN DEN BROECK (1885) gë̈ndert.

In jener Zeit bedeutere "Flandrian" eine pleistozäne Sthich, die an Ende einer langen Serie von Quartär- und Tertiärstufen vorkam. Somir schloß und shließt es noch immer die geologische Tradicion der känozoischen Sequenz ab.

In allgemeinen werden Untereilungen des "Flandrian ${ }^{\star}$, wie z. B. Calais und Dunkerque, gebrauch, obwohl es von beiden Gruppen nur Typregionen und keine Typtokalitïen gibc. Man arbeiter daran, das Typenprofil in beiden Gebieren der Aämishen Küstenflähe zu bescimmen. Auf der Basis dieser neuen Erkenntrisse wäre es empfehtenswerr, die „Flandrian“-Srufe als letzres dronostrarigraphisthes Glied in der kontinuierliden Serie der stratigraphisçen känozoischen Sequenz wieder einzuführen.

\section{Use of the Flandrian}

The term "Flandrian" is the far most widely known connotation which is used in the utmost confusion since ic was rebaptized by Durois in 1924, half a century ago. 
Especially in the Anglo-Saxon literature the name is largely adopted to indicate deposits of the entire post-glacial period in coastal areas mainiy, also however, for continental deposits. Many references are known from the British Isles and the U.S.A., as well as from Australia and New Zealand (Zeuner, Wright, FAirgridge, Flint, Gili, Suggate, West, Shotton).

In the same span of time, the term was highly amended, however, by the French and Belgian authors who were permanenty confrontated with the deposits of the type area of the Flandrian which is in the Flemish Coastal plain: exiending from Sangante near Calais (France) to the Schelde Esmary in Zeeuws-Vlaanderen (The Nerherlands). Acrually, it has fallen in complete disuse, in France, Belgium, The Netherlands and Germany since World War II. Here, terms as "Calais" and "Dunikerque" at the level of Formation superseded the connotation Flandrian, albeit some French auchors may use in wiin rérerence to Calais deposits (Sommé 1969; Coque 1972) only or to Calais and Dunkerque deposits together (Sommí 1972, 1973, 1975).

Therefore, the term "Flandrian" is more safely used by those investigators in connection with the general post-glacial sealevel rise: the Flandrian transgression. So they escape the fact of giving this term a precise meaning.

It is clear that much of the confusion in the terminology of the Flandrian was due to the fact that the name was "misused" peil-mell in the chronostratigraphic, lithostratigraphic and genetic sense. Furthermore, even when used in one of the afore mentioned meanings, it did not cover either the same time span, the same series of deposits, nor the same phase of sea level rise. Actually, there does not exist a type section of the Flandrian, even nor a rype secrion of the Calais and Dunkerque deposits. One can only speak of a Flandrian rype area.

Therefore Flandrian: a formation or just a chronostratigraphic name to store deposits of different nature and origin?

This is somewhar the way it was used on such official documents as the Geological Map of France and Belgium. Whereas on the French maps "Flandrien" is to indicate holocene deposits of the Flandrian marine transgression, one will find back exacily the same name on the Belgian maps as for the pleistocene, Last-Glacial, eolian, fluviatile or/and marine sand loam, crag or/and peat deposits which may be affected by periglacial phenomena as well.

We believe that no further comments are required. But if one is to consider that the French definition was derived from the original Beigian one, he will quidkly realize that it is abour time to get world-wide investigators of the Holocene, alert about the hind of polluted sedimenc they are dealing with.

The present state of the problem is rather paradoxal: on a world wide scale, the term Flandrian is of general use, while on the local basis Calais and Dunkerque have gained more popularity amongst Northwestern Europenn geologists and geographers. Therefore, it was strongly feit by the last mentioned group that a thorough reconsideration of the Flandrian was necessary if not notorious 


\section{Historical review of the name "Flandrian"}

\subsection{The Belgian "Flandrien"}

The term "Flandrien" was introduced in 1885 by Rutot and VANDENBroecs, almost half a century beicre Dubcis' redefinition (1924), ro connotate the relatively thin, freholocene upper mante of sand in Northern Belgium, lying in the continuity of the Dutch coversand. No relation with deposits of the Flemish coastal plain existed so far. Officially it should be reported in the geological legend or December 1991 as "Flandrien (q4)" being the uppermost member of the "Quaternaire inférieur" or "Diluvien". The "Flandrien" or Sands of Flanders are now considered to be of Aluviarile origin contrary to the original interpretation of DumoNr (1839), who pleaded in favour of a marine origin. In April 1896, considerable changes occurred in the Geological Legend and the meaning of the "Flandrien" was enlarged. In fact his was greatly due to recent investigations carried out in the Belgian coastal plain leading to the recognition by both Rutot and Mourlon of the "Flandrien" in this part of Belgium as well. Moreover, in borings just North of Ghent, the "Flandrien" was found to contain amongst others "Corbicula fluminalis" and "Cardium edule" at a depth of more than $15 \mathrm{~m}$ below the surface, which made it possible to make a distinction between an upper continental (original) Flandrien and a lower marine Flandrien (Rutot 1897).

Despite the most remarkable description of the boring of Costende by Detalque (1860) who created the "Assise d'Ostende" in whic Dolifus had recognised at a depth of 25 to $33 \mathrm{~m}$ Corbicula fluminalis (MUILER) already in 1884, no relation was established by MOURION (1896) with the new fossil findings. Yer Dolifus had already put forward the "pleistocene" (quaternaire inférieur) age of these "marine sands of Oostende" on basis of a their malacological content as well as their fresence underneath weathered, continental loam layers similar to those found at the surface in the adjacent loess area outside the coastal plain. Above the weathered loam layers sealing the "Assise d'Ostende", younger marine fossil bearing sands, pear and surface clay and sands were found which Dorlfus adhered to the "terrain moderne".

In fact they respecavely coincide with the presently called Calais deposits under, and Dunkerque deposits above the fent layer.

Is is clear that if Dolifus' description and interpretarion had been thoroughly considered and understood, the Flandrian would have existed without any complex story.

What could be so difficult that left confusion in Rutot's mind during twenty fve years, until he discovered ar Hofstade (North of Brussels), sands ar depth containing Corbicula fluminalis in living position (1910). Let us explain the threads of his thoughts.

After an iniriai long silence, RUtot (1900) rejects vigourously Dollfus' poin of view entirely, stating that in the Oostende boring Corbicula fiuminalis does nor occur in siru nor thar the wearbered loam should be accounred for the equivalent of the Hesbayen loam whicr insead is a loamy facies of the Flandrian. In this new light all sediments below the main pear layer, down to the certiary substrarum, are of Flandrian stage age.

This over-simplification of the stratigraphical sequence in the coastal plain lead to serious errors. First, the coastal plain facies of the Flandrian was extended by A. Rutot 
(1900) to sands containing Cardium edule in the hilly region south of Coastal Plain and beionging to the Yzer basin along the French-Belgian border. These sands are the later to be called "Izencerge Sands" of Holsteinian stage age (TAvernier and DE HeinZELIN 1962, PAEPE \& R. VANHOORNE 1975).

East of Bruges, the continuity of the Flandrian was established along the "Golfe de Gand" (1897) or the Flemish valley (T_1Yernier 1943) from where ar present it is known that the upper part is of periglacial Weichselian origin, whereas the lower Corbicula fuminalis bearing sands and gravels belong to the Oostende Formation of Eamian age (Thvernier 1943, 1946, 1948, 1954, De Mloor 1963 and Paepe 1967). Both deposits are occurring below a modern or holocene pear.

Thus appeared in the Flandrian sediments of different nature and origin, and not at least of different age and climatic period.

New emphasis was given to the Flandrian after the discovery of sand layers with bivalve specimens of Corbicula fluminalis ar HoFstADE (1909). This lead to a renewed interpretation of the borings executed at Leffinghe, Middelkerke, Dendermonde and especially Oostende of which RUTOT (1910) now recognized the correctness of DoLlfus' earlier incerprecation in considering an Old Quaternary or "Moséen" age for the lower marine deposits of the Coastal Plain and in restricting the Flandrian to the sediments above with the exceprion of the peat and overlying polder sands and clays.

It is noteworthy that equal to the boring at Oostende, the layers with Corbicula fuminalis at Hofstane occurred underneath first, a hesbayen loam and second, a "marine" Flandrian deposit in the sense of Rutor (1910).

From this period also dates bads the general assimilation of the connotation Flandrian to deposits which are often referred to as Calais at present. With regard to the lowerlying sands and gravels, with Corbicula fuminalis, the original "Assise d'Ostende" of DEWALUE (1868) has thus been reestablished, however withour precision of its age, nor of its upper boundary.

Instead of being a new point of departure, neither the official geological legend nor Rurot's furcher publicarions and projects will give more atrention to this problem, than before. Instead Rurot was trying under the influence of new theories from abroad to adapt his quaternary subdivision to the climatic classification of PENCK \& BRÜCKNER (1910) or to the archeo-geologica! subdivision of Commont (1912).

After the XI Geological Congress held at Stockholm in 1910, the Flandrian thus became incorporaced into the Würm Glaciation which correlation was abandoned in 1920 , in favour of an assimilation of the Flandrian with the uppermosr "ergeron" of the Somme valley which dronologically is to be considered of Upper Moustérien age. During all these new adaptations the Flandrian remained of marine origin until HALET (1922) drew the artention to the fact that the marine Flandrian was limited to the present coastal plain. Ourside the coastal plain, he considers deposits with Corbicula fuminalis as belonging to deposits of a large delta of Upper Pliocene or Lower Pleistocene age.

In Haler's mind the "Flandrian transgression" had started not earlier than the end of the Pleistocene or even beginning of the Holocene. 


\subsection{The French "Flandrien"}

It is in the same line of thoughe thar Dubols (1927) locares the "Flandrian transgression" in the time spar of End-Pleisrocene-Holocene-Middle Ages, as the fifth transgressive sedimentary cycle of Deprert (1918) just after the Vionastirien. His fieid of investigation is restricted to the coastal plain, and in particular to the area of Calais for the middel stratigraphic layers which are cropping our against the Artesian dome: he also has made an attempt to give a new interpretation to the quaternary deposits of the borings from Oostende, Middelkerke, Leffinghe and Vlissingen.

Dusois (1924) was well aware of the fact that Rutor (1897) had grouged under the same connotarion "Flandrien", the basal marine sands with Corbicula fimmalis MuzIER, the wearhered loams and the lower pare of the upper marine sands of modern age in Doltfus' description of the boring of Oostende (1884). Yet he uses it again and extends the Flandrian to the top with greyblue marine sands which occurred on the Belgian Geological map as "sables gris bleu' (alr 1) of modern age and immediarely appearing under the holocene pear layer (presently called: surface pear).

Thus doing Dubors (1924) is denying Rutot's reconsideration of the beds with Corbicula fluminalis after the findings of HOFSTADE (1910). The reasons herefore muse be searched in a series of studies which went on since $190 \mathrm{C}$ already with regard to this specific fossil itself and to its presence in marine-estuarine deposits in the Netherlands, Danmark and Germany, and which had never been seriousiy considered by Rutot. First of all, Dubors does nor consider Corbicula fuminalis a representative for any specific interglacial phase. Since it is an eurytherm species no climatic signincance may be artributed to it. As to the presence of this fossil in similar deposits of neightbouring countries, Dusors states, that LokIE (1903) had proposed to corrolate the marine Flandrian with the marine eemian deposirs of Vlissingen. These eemian deposits characterized by the presence of Bittium reticulatum and Tapes virgineus, are at that moment adhered to a pre-Rissian, frobably the Tyrrhenian interglacial.

The artribution of the Flandrian to the Eemian was extended to Northern France by BrtQuet $(1906,1907,1908)$ whose believe it was that Eemian was identical to the Würmian. As we have seen above, Rutot (1910) indentifes Flandrian to the Würmian as well, but relates his eolian Brabantian loess to the Eemian interglacial which had become Riss-Wüm at that time.

The assimilation of the Flandrian to the Eemian is contested by the Danish investigator NorDMANN (1908) whose task it had been to make a revision of the faunistical content of the classical borings: Leffinge, Vlissingen, Middelkerke and Oostende.

Fis conclusions were: "No caracreristic species of the Eemian occurs in the Flandrian excepr for Tapes aureus var. eemiensis Nordmand bue which occurs only as 6 worn fragments and two untypical bivaives". Flandrian and Eemian though both of remperate origin, are not identical.

Dubors was quite happy to state that this rejection by Nordmann added to the rejuvenation of the Flandrian which he claimed on basis of the continuity which existed between the Flandrian and the uppermost grey sands. Furthermore, the presence of a molar of E. primigenius at the base of the boring of Coquelles under $15 \mathrm{~m}$ of marine 
peaty sediments, containing neolithic, gallo-roman and even XIII th century implements, covered in turn by younger marine sands laid to the assumption of an EndFleisrocene-Holocene age.

Dubors' assumption was in full agreement with HALET's statement, made two years before, about the age of the Flandrian.

The continuity in sedimentary evolution and timespan are at the base of the renewed creation of the one single concinuous Flandrian cycle including three subseries:

- Lower Flandrian (Assise d'Ostende): berween -15 and - $30 \mathrm{~m}$ with greas abundance of Corbicula fiuminalis; ccrresponding to the Sengiacial of Danmark.

- Middle Flandrian (Assise de Culais): berween $O$ and $-15 \mathrm{~m}$ and with faunal assemblage similar to the present (Zirphaea crispata, Ostrea edulis); corresponding to Littorina and Tapes phase.

- Upper Flandrian (Assise de Dunkerque): about sea level with present fauna (Myaarenatia); corresponding to the Mya arenaria phase.

The identity of the Oostende series is based on Corbicula fluminalis which occurs in siru as wrell as the presence (in several borings, Oostende, Coquelles, Calais) at the upper limic of these series of a "loam or peat layer berween $-15 \mathrm{~m}$ and $-20 \mathrm{~m}$ depth, inferring a standstill in the positive trend of the Flandrian transgression, viz. a shor negarive one".

The identity of the Dunkerque series was based on the presence of a gallo-roman pear formation (= surface pear) a its base.

Hereafter, it is Dubors (193C) himself who will change the chronologic meaning of his original "Flandrien", a concepe which he is still advocaring in 1946. Hereby and in the line of thought of Deperet, the "Flandrien" is considered as the fift aggradacion phase following on the Monastirian, and thus of full Last Glacial in age. This Flandrien should have lasted from 50,000 B.C. till abour 6000 B.C. Hence the subdivision of the "Flandrien" s. 1., is as follows: "Assises d'Ostende", de Calais (=Flandrien s. str.), "de Dunkerque"; but as is stated by DuBors (1946) it most probably will be necessary to extend the "Assise d'Ostende" again, towards the base of the "Flandrien s. L." as our knowledge about it will have grown in the future.*

It is finally the meaning of BrIQUeT which dominares mose the French "Flandrien" investigators. However, on the French geological maps of the northern French coastal plain, the "Flandrien" is subdivided into Calais and Dunkerque.

\subsection{The end of the Flandrian in the Flanders}

In Belgium there was some reaction too; in 1931, at the occasion of some new cored borings near the French border which HAIET was lucky to sudy, he also vigourously attacked the concept of Dubors' Flandrian and rejects entirely the idea of any possible subdivision, quoting that the pear horizon at the limits between the Oostende-Calais and Calais-Dunkerque series are nor continuous and thar several pear horizons are found to exist below the main pear at the base of the Dunkerque series.

$\because$ see page 30 
As a consequence, an Upper pleistccene Flandrian age was proposed again for all marine sands, Oostende and Calais, below the main peat layer; a holocene age for all those above the peat.

One should rememcer that in the Belgian Geological Legend, all former connotations including the Flandrian were abolished since in December 1922, Pleistocene and Holocene were introduced instead of "Quatemaire" and "Modeme".

Is clearinies why in a series of short notes about findings of Corbicula fuminalis at St.-Denijs-Westrem (1933), Templeuve (1937) and Escanarfles (1939) Haret will never mention the name of Flandrian again.

Tavernter uses the tem Flandrian again, first in the sense of Rutot, in his publicarion on periglacial phenomena (1940), lazer in a combined Rutot - Dubors - Halet definition as of 1943 when describing the deposits of the Flandrian transgression. For the first time, a relation is established between the Flandrian and the Upper-Holocene, more especially with the Atlanticum as to the age of this transgression.

In the same line of thoughe, the main pear layer was considered to be Subboreal, and the Dunkerque transgression, Subatianticum in age.

The pear at depth separating the Flandrian deposits from the underlying deposits with Corbicula fluminalis is accounted for Boreal in age. TAvernier introduced Upper Flandrian to designare all sediments of Post-Glacial Holocene age and Lower Flandrian for all Würm-Glacial sediments.

Deposits with Corbicula fluminalis then belong in TAverNLER's opinion to the RissWürm or Eemian marine transgression, as well as their continental equivalents (1943).

In 1946, however he rejects his own earlier opinion in considering the "Assise d'Ostende" with Corbicula fumminalis as an interstadial of the Wümian, including all deposies of the Flemish Valley.

Thus he rerurns to Dollfus' interpretarion where "Oostende" of Würm interstadial age almosr equals "Quatemaire inférieur", "Calais" of Holocene age, the "Quaremaire supérieur" and separated from the Würm decosits by the intercalated loam layers of Late Glacial age (" $=$ Tardiglaciaire). It is the first reappearance in Belgium of the term "Calais".

As of now, Calais will only be used to assign deposits of the Flandrian transgression equal to the Littorine littorea transgression of the Baltic. The Dunkerque deposirs (TAvernier 1948) will not be included to the Flandrian, thus going back to Rutot and Halet. The first subdivision into three phases of the Dunkerque transgression is announced.

The importance of 'TAVERNIER's work refers to the definite and undubious separation of the Oostende, Calais and Dinkerque deposits.

The Oostende series will further develop from Würm Interstadial $(1946,1948)$ to Eem interglacial (TAvERN!ER 1954, 1957), the Calais series to deposits of the Flandrian Atlantic transgression and the Dunkerque series, to deposits of the Dunkerque, Subatlancic transgression. 


\subsection{The International "Flandrian"}

In his famous book "Daring the Past", ZasuNer (1946) recommends the use of "Dubors' term, Flandrian, for the rise of the sea from the low level of the Last Glaciarion to the comparatively high level of the present day ...". It extends from slightly before the Post-Glacial rill Present.

WRIGHT (1937) also refers to Dunors' definition in the third edition of his book "The Quaremary Ice Age": "In 1924 Dubors described under the formational name Flandrian a series of deposits lying mainly below sea level and forming the marime plain of Flanders, and these deposirs have recenty been shown by CHAput (1928) to have a wide distribution along the whole Arlancic coast of France. The surface of the plane rises $3-4$ metres above mean sea-level, and the base of the deposits rests on Creraceous or "Terciary beds ar a deprh of 20-30 metres".

WRIGHT also remembers to Durcis subdivision into a Lower, Middle and Higher Flandrian without referring to the Oostende, Calais and Dunkerque.

Fint (1957) in his "Glacial and Pleistocene Geology" remembers to the use in Europe of the name Flandrian to connotate "sediments deposiced by the marine transgression that has accompanied the last major deglaciation" (cfr. Dubors 1924 and 1930).

WEST (1968) clearly separates the chrono- and litho-stratigraphic term which is the Flandrian from the connotation Late Weichselian, while he also uses it commoniy for continental and marine deposits.

We could go on to repor on the use in the Angic-Saxon litrerarure, but one is already convinced that the need of such stratigraphic term was feis world-wide.

At the moment the term was launched in the Anglo-Sason lirerature, it was rejected in its type-area, the Flemish (French-Beigian-Durch) coustal piain. The French investigators continue to use it in different ways: either in the sense of BRIQUET, or in the meaning of Holocene deposits or still as the equivalent of the postglacial transgression (TERS 1973).

WOLDSTEDT never mentions ic in his fomous works "Das Eiszeitalter" (1954) and "Quartär" (1969), nor do the German holocene, marine investigators as a whole.

In the Netheriands where marine Holocene deposits buid up to major part of the Western part of the councry, "Flandrian" was used for the last rime by BenNema in 1954.

In the meantime, Calais and Dunkerque series were commonly used by the Soil Survey Centre of Belgium under impulse of TAVERnifr, ever since 1948. From here, the two terms gain the Durch holocene again and was officialized by DE JONG \& HAGEMAN 1960 in the official legend of the Geological Map of The Netheriands.

As a creation from the same author, the Holocene North Sea Formation was presented to the members of the Holocene Commission of INQUA in 1970. It comprises three nembers: Calais, Dunkerque and Holland Pear member.

Renewed investigation lead to the recognition of at least five Calais and four Dunkerque levels, separated cne from anorter by a level of the Holland pear (HAGEMan 1960, JelGersma 1961, Wiggers 1962, Roeteveld 1974).

New investigation in the Calais region (Sommé 1972, et al.), and the Belgian Flemish 
coastal plain (Paepe 1971, 1974 and Baeteman 1974) lead to the same conclusions about the existence of several sedimentary phases, which resules fit observations of N. W. Germany (SindowSKI \&. StreIF 1974) and N. W. England (Toolex 1974).

\section{The Flandrian Problem}

3.1 The confusion about the Flandrian first results from the face that this term is used in the Anglo-Saxon world to indicate the post-glacial deposits solely while in Dusors opinion it startad already ar the end of the Pleistocene. Hence rhere is a cironostratigraphic confusion about its world-wide use at the present. If the Flandrien were to be limited to the Holccene, then the Pleistocene-Holocene boundary has to be reconsidered first (MORNER 1969).

3.2 In the sense as described above there is also a litho-stratigraphic contusion, for the "Oostende series" do nor belong to the same cycle of sedimentation or even sez level rise as the "Calais" and "Dunkerque". PaEpe et al. (1971, 1972, 1973) have shown the existence of periglacial deposits with frost-wedges and cold peat in berween the "Dunkerque series" and the "Oostende series" ar Brugge, Meetkerke and Oudenturg in the Belgian Coastal plain.

In the Oostende series, Tapes senescens var. eemiensis and Corbicula fuminalis were found in situ (bivalves) in wad deposits overlying older coversands. Earlier Paspe (1965) had discovered the first bivalve of Tapes senescens var. eemiensis in a boring at Stalhilile nearby Oostende.

All these findings have been confirmed by many other authors (DEMOOR 1970, 1972, Nolf 1974, Gurlentors et al. 1974). Thereiore the Flandrien deposirs are limired towards the base, by the lower boundary of the Calais deposits. This lower limir must thus be ascertained and it very much seems that in the Calais area, there are Calais sediments prior to Calais.

3.3 In the Belgian and Erench coastal plain, there is usually a thidk main pear layer (as in the Calais area) between the "Calais" and "Dunkerque" series. We know that the pear growth stared abour 4500 B. P. and ended somewhar abour 2500 B. P. in the Belgian Coastal Plain. Clay lenses occur in this pear occasionally. Recent studies in the Coastal Plain however revealed the existence of prominent clastic horizons subdividing the peat in phases similar to the ones found in the Nerherlands and Germany. ${ }^{14} \mathrm{C}$ darings seem to coincide in different parts of the Coastal Plain and also show several phases of Calais and Dunkerque which do not appear in the 4500-2500 B.P. pear.

As a consequence we are favourable to the idea of a continuous sea level rise from the base of Calais rowards the top of the Dunkerque. We propose to call this the Flandriañ.

3.4 The reason of major litho- and chrono-stratigraphic confusion is due to the fact that the paleo-geographic distribution of the Oostende, Calais and Dunkerque series was 
not known precisely for long. In some area's Calais deposits with Corbicula and Tapes are found from the main pear down to the Tertiary substratum.

In other places, as in Oostende, pars of the non-eroded Oostende series with Corbicula and Tapes in situ, are found below the Calais. When pear or other marker layers do not occur along the boundary, it is diffcult to disentangle the two facies.

3.5 The redefinition of the Fiandrian should not impose any frustration. Numerous are the redennitions of geological connotations in the pre-quaternary and we know that Eemian changed a lot before its present content became established.

Therefore, rather than introducing new names, we prefer "Flandrian" to "Holocene North Sea formacion".

Flandrian not only has stratigraphic priority to redefinition bur also origined from a geological tradition in the study of the Cenozoic formations of North Western Europe and of Belgium in particular. Indeed, atter the retrea of the Tertiary North Sea from Southwest to Northease Belgium (Diestian to Merissemian), Quaternary seas remained for long in the Northeast along the Dutch-Belgian berder throughout the Tiglian, and Waalian.

Hereafter the retreat towards the northeast came to an end and marine activity became more important in the very southem part of the North Sea, as a direct consequence of the opening of the Dover Strait somewhere during the Cromerian (PAEpe \&: SoMmé 1975).

The tradition switched over to transgression from the souch-west resulting in the building up of Cromerian, Holsteinian, Eemian and finally Flandrian deposits in the Flemish coastal plain of France, Belgium and the Netherlands, which continuation is found in Holland, Friesland, N-W-Germany and Danmark. Flandrian is the last in the radition of at least five known sourhwest North Sea transgressions.3

\section{References}

Alimen, H. (1967): The Quacernary of France. - In K. Rankama, The Quarernary, Vol. II: 89-238.

Baftemlan, C., G. Lambrechts \& R. Paepe (1974): Aurosnelweg Brugge-Calais. Secrie VeurneFranse grens. - Prof. Paper, belg. geol. Survey, 2: 1-55, Brussels.

BENNEMA, J. (1954): Holocene movements of land and sea level in the coastal area of the Nerherlands. - Geol. en Mijnobow, n. S. 16: 254-264, Den Haag.

Bourdier, F., J. de Heinzeinn, R. Tavernier \& S. Vander Hietde (1967): Lexique stratigraphique inrernarional, Vol. I, Europe, fasc. 4 b, France Beigique, Pays-Bas, Luxembourg: Quacernaire. Paris.

BrIQUet, A. (1906): Noces sur quelques formations quaternaires du Litroral du Pas de Calais. Ann. Soc. Géol. Nord, 35: 211-236, Lille.

- (I9C6): Contriturion ì l'étude des origines du réseas hydrographique du Nord de la Belgique. - Mém. Soc. belge Géol. 20: 71-88.

- (1907): Nore préliminaire sur quelques points de l'hisroire plio-pléistocene de la région gallobelge. - Ann. Soc. Géol. Nord, 36:2-44, Lille.

3 The term transgression is used here in its original meaning whic points ar an increase in geographical extension as a resule of displacement of the shoreline. 
Briqurt, A. (1908): Sur une excursion dans le Pléjstacène du Nord de la Franca en compagnie de M. le Pró́. Leveretr. - Ann. Soc. Géol. Nord, 37: 293-296, Lille.

- (1930): Le lirtoral du Nord de la France er son évolucion morphologique. - Thèse: 439 p., Paris.

Commont, V. (1912): Chronologie es Stratigraphie des industries protohistoriques, néolithiques er paléolirhiques dans les déọots holocènes et pleiscocènes du Nord de la France. - Congr. incern. Anchr. Arch. Préh., 14: 239-254, Genève.

CoQLe, B. (1972): Rechercies sur les formations quaternaires ex le modelé de la Flandre marirjme dunkerquaise - Cahiers de Gécgraphie physique 1: 45-6j, Lille.

IE JoNG, J. D. \& B. P. Htgeman (1960): De legenda voor de Holocene Afzeringen og de nieuwe Geclogische Kaart van Necierland, Scraal 1:50.0co. - Geol. en Mijncouw 39: 644-653, Den Has.

Demoon, G. (196j): Bijdrage toc de kennis van de fysische landschapsvorming in Binnen-Vlannderen. - Soc. belge Etud. Géogr. 32, 329-435, Brussels.

- in W. De Breucx, G. Demoor Sx R. Marechal (1969): Lieostratigrafie van de KWartaire sedimenten in her Oostelijk Kustgebied (Belgie). - Nat. Wer. Tydscir. 51: 125-137, R11rweroen.

- (1973): Sedimentclogie en stratigrafie van enkele pieistocene afzeringen in de Belgiscise kustviakre. - Nat. Wer. Tijdscir. 55: j-96, Antweroen.

Deperet, CH. (1918-1922): Essai de coordinatica dronologique générale des rempg quaternaires. - C. R. Ac. Sc. Paris: $166-174$, Paris.

Devalque, G. (1868): Prodrome d'une descriprion géologique de le Belgique. - +42 p., Brussels.

Dolnfus, G. (1884): Le terrain quaremaire d'Ostende er le Corbicula fuminalis Mülzer. - Mém. Soc. Roy. Malac. Belg., 19: 3-29, Brussels.

Dubors, G. (1924): Recherches sur les terrains quatemaires du Nord de la France. - Mém. Soc. Géol. Nord, 8: 353 p., Lille.

- (1930): Un rableau de l'Europe Aandrienne. - Livre Jubilaire du Centenaire de la Soc. Géal. de France, 1: 261-277, Puris.

Dumont, $A$. (1839): Rappor sur les rravaux de la carre géologique pendane l'année 1839. - Buil. Acad. roy. Sciences, 6, 2: $464-485$, Brussels.

Edelman, C. H. Sx R. Tavernier (1940): Periglaciale Verschijnselen, meer in her bijzonder in de Antwerpse Kempen. - Nac. Wee. Tijdschr. 22: 139-153, Antwerden.

Fairaridge, R. W. (1961): Eustatic changes in sea level. - Physics and Chemistry of the Earth 4 : 99-185.

Fint, R. F. (1957): Glacial and Pleiscocene Geology. - 553 p., New York.

Grr, E. D. (1971): The Paris Symposium on World Sea levels of the past 11.000 years. Quacemaria XIV, $9^{\circ}$ INQUA Congress: 1-6, Paris.

Halet, F. (1922): Le Quatenaire dans le Nord de la Flandre belge. - Bull. Soc. beige Géol. 32 : 152-162, Brussels.

- (193j): Sur la présence de couches à Corbicula fuminalis Müller aux environs de SaineDenis-Westrem. - Bull. Soc. belge Géol. XZIII, 111-116, Brusseis.

- (1937): La Géologie de la Vallée de I'Escaur, à Tamise. - Bull. Soc. belge Géol. 47: 356-362, Brisseis.

- (1938): Sur la présence de Corbicula fuminalis Mürzer près de Templeuve. - Bull. Soc. beige Géol., 48: $577-578$, Brussels.

- (1939): Sur la présence de "Corbicula fuminalis" dans le Pléisrocène des environs d'Escanaflles. - Bull. Soc. belge Géol., 69: 233-234, Brusseis.

Jesgersma, S. (1961): Holocene Sea level changes in the Netherlands. - Med. Geol. Stiching, Serie C, VI-7: 100 p., Masstriche.

Lorie, J. (1903): Sondages en Zélande ex en Brabanr. - Bull. Soc belge Géol., 17: 203-258, Brussels.

Madsen, V., V. Nornmann \& N. Hartz (1908): Eem-Zonerne. Studier over Cyprinalerer og ondre Eem Aflejringer i Dammark, Nord-Tyskiand og Holland. - Danmarks geol. Undersøgeise, II, 17: 1-j02, Copenhagen.

Movrlon, M. (1896): Ies mers quaternaires de la Belgique, d'apres l'érude géographique des dépòts flandriens et cumpiniens et laurs telations avec les couches terriaires pliocenes. - Bull. Acra. Roy. Belg. Se 32, 3me série: 671-711, Brussels.

Nolf, A. (1973): Mollusken uir het marien Kwartir te Meerkerke (West-Vlannderen, België). Nar. Wer. Tijdsctr. 55: 97-120, Anrwerpen. 
Ptepe, R. (1971): Autosnelmeg Brugge-Calais - Kb Hourave, Bredene, Gistel - Proi. Pader, 9, Belg. Gzol. Survey: 59 p., Brussels.

PAEpe, R. So J. Somú (1975): Marine Pleisrocene Transgressions along the Flemish Coast (Beigium and France). - IGCP report No 2, Salzburg, 1974.

Paeme, R. at R. VANHoorne (1967): Stratigrapiny and Palaeobatany of the Late Pleiscoeene in Belgium. - Memoir Geological Map of Belgium, 8: 96 p., Brusseis.

- (1972): Marine Eemian Deoosirs ar Meetkerke (Belgian Coastal Plain). - Pror. Paper 7: Pp. 13.

- - (1975): The Quaternary of Belgium in its relationship to the stratigraphical legend of the geological mad. - Memoir Geological Mao of Belgium 18, in press, Brusseis.

P.tere, R., R. Vanhoorne \& D. Deraymaeker (1972): Eemian Sediments near Bruges (Belgian Coastal Plair.) - Prof. Paper 9: po. 12

Pencx, A. \& E. Bructrer (1901-1909): Die Alpen im Eiszeizalter. - 3 vol., Ieipzig.

Roeleveld, W. P. (1974): The Groningen coastal area. - Ph. D. ihesis, 249 p.r Amscerdam.

Rutor, A.: Les origines du quaternaire de la Belgique. - Bull. Soc. belge Géologie 11: 1-40, Brussels.

- (1900): Noce sur la posicion strarigraphique de la Corbicula fiuminalis dans le couctes quarernaires du bassin Anglo-Franco-Belge. - Mém. Soc. belge Géol., 14: 1-24, Brussels.

- (1910): Sur la découvere de Corbicula fluminalis à Hofstade. - Bull. Acad. Roy. Belg. Sc., 7: 163-169, Brussels.

Rutot, \&. \& E. VAN DEN Broecx (1885): Nore sur la nouvelle classification du terrain quarernaire de la Basse er Moyenne Beigique. - Bull. Soc. Roy. Malac. de Belgique, 20: $3-7$, Brussels.

Shotron, F. (1973): Discussion of the Classification of stages in the British Quaternary. Absrzers IX INQUA Congress: 325-326, Paris.

SINDOw5KI, K.-H. \& H. STREIF (197t): Die Gesćiduce der Nordsee am Ende der letzten Eiszeit und im Folozïn. - In: Wolnstept \& Duphorn: Norddeursciland und angrenzende Gebiece im Eiszeirairer, 411- +31 , Stumgart.

Sommé, J. (1969 a) : La plaine maritime. - Seprentrion, 1, 3-4: 52-55, Calais.

- (1969 b): La plaine maritime. - In: Géologie du Nord de la France. Ann. Soc. Géol. Nord, 99: 117-126, Lille.

- (1973): Les formations quaternaires de la région du Nord. - Ann. Scientif. Univ. Besançon, Géol., $3^{\circ}$ série, 21: 97-102, Besançon.

- (1975): Les plaines du Nord de la France et leur bordure, érude géomorphologique. - Thèse, 790 p., Paris.

Somme, J. \& M. Cabal (1972): La plaine maritime dans la région d'Ardres (Pas de Caiais) ee le site archéologique des Noires-Terres. - Cah. Géogr. phys., 1: 29-43, Lille.

SugGats, P. (1968): Post-Glacial sea-level rise in the Christcurci metropolitan area, New Zealand. - Geol. en Mijnbouw, 47: 291-297, Den Haag.

Tavernzer, R. (1943): De Kwartaire afzettingen van Belgie. - Nac. Wee. Tijdsctr. 25: 121-137, Ancwerpen.

- (1946): L'érolution de Bas-Escaut au Pléistocène supérieur. - Bull. Soc. belge Géol. 55: 106125, Brussels.

- (1948): Les formacions quaternaires de la Belgique en rapgor avec l'évolucion morphologique du pays. - Buil. Soc. belge Géol., 57: 609-641, Brussels.

- (1954): Le quaternaire. - In: Prodrome d'une descriprion géologique de la Bełgique, 565-589, Brussels.

TAVernier, R. \& J. DE Fetnzeln (1962): De Cardiumagen van West-Vlaanderen. - Nac. Wet. Tijdschr. 44: 49-58, Antwerpen.

Ters, M. (1973): Les variations du niveau marin depuis 10.000 ans, le long de littoral atiantique français. - Le Quaremaire, LX Congrès INQUÁ, CNRS Paris: 114-135, Paris.

Toonsy, M. J. (1974): Sea level hanges during the lase 9000 years in North-West England. Geogr. 140: 18-42, London.

VANDENBerghe, J, N. VANDEnberghe \& F. Gullentors (1974): Late Pleistocene and Holocene in the neighbourhood of Brugge. - Med Kon. Acad mer, Lert. en Sch. K. Beigië, 36, 3: $3-77$, Brussels.

WEST, R. G. (1968): Pleisrocene Geology and Biology. - 377 q., London.

Wiggers, A. J, F.H. DE JoNg \& K SPANTER (1962): De Bodemgesteldheid $\nabla$ an de Noordoostpoiders Directie der Ijsselmeerpolders, Rapp. en Mededelineen inzake de Droogmaking Ontginning en Sociaal-Economische Opbouw der Ijsselmeerpolders, Nr. 33: 139 p. 
Woldstedt, P. (1954): Das Eiszeitaiter. - 3 vol., Sturtgart.

- (1969): Quartïr. - 256 p., Stuttgrer.

Zsuner, F. (1946): Daring the Past, - +74 p., London.

Haos

Carre géologique déraillée de la France ì $1 / 80.000$

- Boulogne-Calais: 1964, to údicion

- Calais-Dunkerque: 1876, $1^{\circ}$ édition (Dunkerque), 1978, $1^{\circ}$ édition (Calais), 1939, $2^{\circ}$ édicion

Carte géologique de la France d̀ $1 / 50.000=$

Cassel XXII1-3, 1968; Guines XXII-3, 1971; Marquise XXI-3, 1971.

Lúgende de Ia Carte géologique de la Belgique ¿̀ $1 / 40.000$

- $1^{\circ}$ édicion 1892 (Ann. Soc. géol. de Beigique, XIX, 107-120)

- $2^{\circ}$ édition 1896 (Buill. Soc. belge de Géologie, X)

- 30 édition 1900 (Bull. Soc belge de Géologie, XIV)

- to édition 1909 (Ann. des Mines, XIV)

- jódition 1929 (Ann. de Mines, XXX, 1re Liv.)

Addentum to page 23 :

In 1930, Briquet referring to the definition of 1896 on the Belgian Geological Legend, pleads in favour of preserving Flandrian to all marine deposits of the coastal plain beneath the main pear layer level. Actually, he distinguished a major break at this levet in the positive post-glacial sea level rise, pleading in favour of a distincrion berween Flandrian and Dunkerquian transgressions and sediments. With regard to the absolute age, the Flandrian is post-glacial which he believes to have started abour 7,000 y. ago when compared with the Litto vina transgression of the Baltic; the Dunkerquian transgression would have started only in the IVth century after the Roman occuparion.

Typescripr received May 15 th 1975 


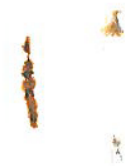
1 